DOI: $10.20472 / \mathrm{TE} .2016 .4 .4 .005$

\title{
AUTHORITY IN THE CONTEXT OF THE INTERGENERATIONAL RELATIONS
}

\section{ALENA VALISOVA}

\begin{abstract}
:
Article focus on question of authority in the context of intergenerational relationships. The main objective is to analyze the philosophical, pedagogical and psychological base. The text focus on the value orientation of youth in relation to adults and the senior population. Questions are asked and indicated inspiration, which are sought answers.

In the same way, as it is adjudged to individuals or social groups, authority can be related to scientific fields, philosophical theories and even to social institutions. What is the place of contemporary school within this intersection of relations? Does it reflect the crisis of culture, society and democracy? What is authority based on? To what extent is it necessary to deal with authority in the period of its indubitable crisis? Is there anything new we can discover in this area? To what extent is it useful to consider authority a pedagogical problem?
\end{abstract}

\section{Keywords:}

authority; intergenerational relations; social competence; older generation; rights; freedom; responsibility; youth

\section{Authors:}

ALENA VALISOVA, Czech Technical University in Prague, Masaryk Institute of Advanced Studies, Department of educational and psychological studies, Czech Republic, Email: alenaval@atlas.cz

\section{Citation:}

ALENA VALISOVA (2016). Authority in the context of the intergenerational relations. International Journal of Teaching and Education, Vol. IV(4), pp. 60-69., 10.20472/TE.2016.4.4.005 


\section{Introduction}

The twenty-first century has been identified as a century of communication, where their place will have the socially mature, even-minded individuals, with competence of effective conduct, who are able to take rational decisions in critical and conflict situations, keep adequate self-control, solve problems, discuss and use logical arguments, convince and negotiate. However, is it possible to manage all these in the contemporary over-technologized environment and increasingly dehumanized world? Can the young and successful people live next to each other with older and sometimes already tired people in a certain harmony? After all, the age and tiredness - this is nowadays not trendy! The main objective is to analyse the philosophical, pedagogical and psychological base of the authority. The text focus on the value orientation of youth in relation to adults and the senior population. It monitors issues are asked and indicated inspiration, which are sought answers, the problematics authority and their related to scientific fields, philosophical theories and even to social institutions.

\section{Changes of the social processes and their impact on the intergenerational continuity}

The position of a man in the contemporary world is very complicated, non-transparent, considerably unstable, the mechanisms of the social regulation become loosen, they are removed and the new one are not always distinctly structured. The traditional behaviour, that enjoins to act according to the time-proven paradigm in an expected manner, is limited to the exceptional situations or cases and only rarely respected. Nor the social regulation's form of value of the type "standard - fulfilment" (even though the present differences between the content of the social demand and the personal interest are taken into account) sometimes does not reliably lead to the anticipated internalization. Relations of the social interaction are subject to rapid changes and on the outside can again leak the "restored attendant phenomena" - the loss of identity, loneliness, problematic use of the leisure time, growing consumer attitude to the life, mentality of ruthlessness, moral relativism, low self-control, lack of tolerance and discipline, loss of dutifulness and own responsibility, emotional instability, relativization of values and authority. The mentioned phenomena are to a certain extent negatively reflected in the professional, family and personal life each of us - irrespective of the age criterion.

Professional and non-professional discussions on the issues of freedom, responsibility, decision making, authority, democracy, rights and duties, discipline, self-control, morale and values are ever more frequent in our country. Intensively are also heard voices that call for the reform of the society, for restoration of the respect to the ethical and legal standards, regulations and laws. Someone sees the way to this reform in augmentation of the influence of the church and advocacy of its moral code in the form of Ten Commandments, other in restoration of the traditional family with all its former functions 
or in professional realization whereas other see it in the work of the school or legislation, and many see it in combination of all these points of view.

The aforementioned negative phenomena in the society can be summarized into the following blocs:

- Plurality of the life forms and social relations;

- Ethical and economical problems

- Multi-culturality;

- Virtual and medial reality;

- Transformation of the family and other partner relations;

- Relativization of the authority.

\section{The "Cult of Youth" is getting near to an end?}

The world history knows many conflicts that in an escalated situation take the form of a war. Wars that are led by fists and spears or by mere teeth but also by firearms or bombs, defensive and destructive wars, civil wars and wars between civilizations. Apart from all these wars however exists also the "ware of generations" - as far as we understand the generation as a group of people of the same age who lived in the identical historical period. In this war, the armed forces do not fight at the battlefield, the people are not shot and no captives are taken. The generation conflict nevertheless sets in motion deep and powerful strengths, biologically and socially conditioned, that it is quite natural to speak about them as of a war. In a certain sense is the war of generations the oldest one and at the same time the most modern one from all these wars. It is the oldest because it is programmed biologically. It is the most modern because the mankind leads it already for a millennium as a psychological war, the war of words and humiliation.

At the contemporary stage of the social development it is impossible to reason that the only force that intends to catapult our society into the middle ages is the militant Islam. Also our culture and the quality of intergeneration relations faces new middle ages. As far as our ideas about aging in our society will not be adjusted to the new development, the older generation and seniors will spent the autumn of their life in the new middle ages. From the present point of view taken, something from the medieval atmosphere of destruction and disintegration stretches over the world after 2010 but contrary to the middle ages without any optimistic faith and hope in salvation.

Naturally it is not possible to state a precise date when the "bang" between the young and old people will break out. The rift is creeping almost as an imperceptible shift inside and outside of the society. Many people nowadays believe that it will be only a "negligible socio-political problem". But in fact it will be a matter of a dramatic global confrontation. The influence of aging will be felt both in internal and external policy. The 
poverty line henceforth will not lead between the North and the South but to a considerable extent between the "young" and the "old" countries. As far as the countries with nowadays low wages, in particular the China, will succeed in building of pension systems, fully financed by the state, for their own aging population, they will produce even bigger capital reserves. This circumstance could cause that some of the contemporary aging great powers could be entirely dependent on these reserves, in order to maintain their own ability of action. The states at the different degrees of their existence will enter into the new economic relations and the generations will qualify themselves alike. What will come of it? Will the international diplomacy undergo a change?

The states that are found at the different degrees of their existence will enter into the new economic relations and the generations will circumscribe themselves alike. One thing is however certain: even if it will be possible to increase the birth curve immediately tomorrow, the downswing of population will be moderated only after thirty years and only after sixty years the number of population will start to grow. We will live at the same time period with our parents but if the forecasts are right also with our aging children.

Such prospects into the future can evoke atavistic dreads. What nowadays looks just like numbers in the statistics we will be ourselves in the future. We will be compelled to listen to the loud debates about the overly number of people, discussions on euthanasia, on incurable cases of people and their last weeks of life, the costs of which represent a huge burden for the social system. There does not exist any experience that could suggest what will happen in the highly modern society when a great number of old people will get together with a much smaller number of young people.

Our main battlefield is the time. The stone-age man did not live to be even forty. The majority of us now live to be forty and has at least twenty five years of active life at work before one (if we can find an appropriate work for the subsistence and selfrealization....). In the face of the mentioned facts there exists only one thing we can do for our children: get older in a right way. We can be alive for a long time but at the same time we must keep a firm steadfast self-confidence. Let us become a real and respective authority for the young people in our own family, in our working environment and our personal life.

\section{Authority - its growth, fall and slow comeback}

Irrespective of the fact whether the authority is or is not a theme for standard discussions, the hitherto history of mankind bears the witness of glory and misery of the authority gained and lost. The twentieth century and the beginning of the twenty-first century are also a proof of it - two world wars, holocaust, revealed crimes of the authoritative regimes and imperial adventures of great powers, leave the mankind with a shaken trust in authorities, in simple recipes for ideal changes of the society, anchored traditions and moral codes. The period of chaos seems to be calling for authority, whereas the period of iron hand rule in most cases leads gradually to its refusal. In case 
that the scepticism, resulting from the crises of the authority, has gradually found its expression in postmodernism as of a certain interim period, the logic of the history suggests that we are approaching another crossroads. The beginning of the new century seems to accelerate the forthcoming change. What the future society will be like? On what kind of authority will it be based? How will it be reflected in the relation between the adult and child in the family and school environment? What impacts will it have for the intergeneration relations?

The theme of authority at present goes beyond the significant traditional viewing and gets to the new connotation that take into account:

- Status of the individual in the society,

- Need of freedom and self-realization of the individual

- Ability of orientation in complicated social relations and demanding life situations,

- Importance of the individual and social responsibility, self-control and volitional effort,

- Personal characteristics

So, as we can attribute the authority to the individual persons or social groups, we can relate it also to the scientific fields, philosophical theories but also to the social institutions (Novotný, 1997). Authority, in the context of the intergeneration relations, can be viewed as an interrelation between the bearer (i.e. a person who exerts direct influence on his surroundings) and the recipient of the authority (i.e. the addressee of the influence who respects, acknowledges the bearer of the authority and in some measure accepts him).

One of the aspects in the conception of the authority is important for the intergeneration relations and this is the aspect of relativeness. The individual acquires the authority in a certain time period, towards his social environment, towards certain people, particular groups (for example at the workplace, in his family, in an interest group). However, he need not have the same "degree of authority" in different spheres of his activity, in different social groups, he can have it for example in a certain time period and also in relation to the particular members of the group (Adorno, 1969).

With respect to the etymology of the term of authority we can learn that the Latin term auctoritas means support, guaranty, certainty, responsibility, credibility and many other positive meanings. The related word auctor represents somebody who helps, supports, a paradigm, an example, predecessor. The base of both words - augó - expresses the verbs that mean support in growth, augment, multiply, uplift, enrich, endow. The social reality and the historical process however sometimes do not pay attention to the etymology, they shift and change the content of the meaning (conception of the authority, apart other things, has been influenced by sociological and political studies on relation of the authority and power, authority and government, authority and social pressure). 
If we take up the definition of the authority nowadays, we can for example state that the authority is by definition an anthropologic invariable that jointly sets the rules for the life of a group, its organizational order, jointly conditions its biological survival, development of the individuals and transfer of experiences from generation to generation. It becomes a guarantor of the positive value structures and traditions, an important precondition for the development of human abilities and becomes a base for functioning of the society in the broadest sense of the word.

And how is it with the adjustment of older people to the modernization trends and innovations? Young people permanently seek the innovations, as it is their natural need. They want to acquire new and new experiences as these form their driving force. According to the majority opinion, older people and seniors, on the contrary, they do not need a lot of innovations as they prefer time-tested practices. The attitude towards innovations is of course also a matter of education and professional orientation and the hidden stereotypes of the mass culture or fixed standards of the sub-culture cannot avoid even the young people. Once again, it is the matter of acquired experiences and attitudes. In management of the state, enterprises and also family should therefore be represented both generations as their functions complement each other. For that reason it is a pity that currently so many firms and enterprises take to their teams only young, ambitious, go-getting but on the other side inexperienced people. They refuse an older man at the entrance examination due to the common awareness that older applicants will be slower, can be frequently absent for health reasons (connected with the age) and are not able to work according to the newest technological trends (this phenomenon however self-evidently relates to the kind of work the older applicant tries to win - other experiences needs the owner of a joiner's shop and another an advertising agency).

\section{From intentions to the actions or active lifestyle}

Each of us reacts to the suggestions of the outside world in a certain manner, expresses one's own feelings and ideas, accepts or does not accept the opinions of the others, overcomes the life obstacles in a certain manner and solves the potential conflicts. The common living practice reminds us constantly of the importance of willingness, volitional processes and volitional qualities. The majority of human beings is all life through faced with the necessity to develop self-formation and self-training in order to overcome the outside and inside obstacles. Sometimes it is more important - and at the same time more difficult - to show a firm determination in the everyday life, filled with the ordinary work, rather than in the heroic deeds.

Intergeneration dissonance, apart other things, are at present instigated by the discussions on the matter of freedom, responsibility, decision making, democracy, discipline, self-control, morale and values. Topical becomes searching answers on the issue of the purpose of life - that is across all the generations. The old philosophical formulation, "become such a man as you are", is not only a requirement to develop one's own talent, ability, endowment or skills. It appeals on the own activity of the 
person: "You will realize yourself and become such a man that you can and must become if only you yourself will want it, should you be able to make a right choice in your life and if you will exert every effort to its realization."

Each generation bears on itself a sign of the period in which it has matured and consolidated its position in the society. At the time, when the hierarchy of values is ruled by the money and strong belief that "everything is allowed and nothing is forbidden", it is not uneasy to deny the necessity to conform to the rules of the elementary decency and the standards that otherwise form a base of the security and existence. Many movements for children and youth rights are often paradoxically mistaken, when they claim the rights on their behalf and at the same time forget to speak about the duties. It is a pity that the rights of the older generation and seniors are not presented and enforced in the same measure.

Relations between the generations, in the family and in the professional environment reflect the degree of the natural and voluntary sharing of the commonly valid system of standards, rules and requirements - extension of the independence requires the growth and respect of the responsibility, rights, duties and also rules of the mutual coexistence (the social model of three P).

\section{Characteristics Model 3 P - Order, Rights, Duties}

\section{Order:}

Order is a constantly changing state that on the one side enables to fulfil the required duties and on the other side to fulfil the rights of the individual

\section{Rights:}

Rights of the individual form a set of conditions that secure the adequate development of the individual in the biological, psychological and social sphere.

\section{Duties:}

Duties can be conceived as the rights of a social unit towards the individual that exist for example as taboo, standards, values or laws. Many of them are liable to sanctions, if they are not fulfilled,. For the developing individual is its adoption relatively demanding.

The gradual incorporation into the "world of adults" and the "world of particular authorities" does not consist only in the knowledge of the standard as such (legal, moral, working and others) but primarily in the ability to understand its sense and conform to it in the practical activity, act in its sense (the problem of exteriorization and interiorization). This ability necessarily anticipates the control of both the "instinctive behaviour" and the discrepant points between the "wishes" of the individual and what is requested from him." In the course of formation of this ability it is necessary to take into account the inter-individual differences and the social dynamics, however this differentiated approach can hardly change something in the substance of the fact what falls or does not fall into the lack of discipline or responsibility. Even if it can concern (in 
the case of fraud, theft, aggression and other crimes) a more complicated phenomenon, in which can be dominant another point of the problem and when the implicit freedom to make a choice of the action alternative at the same time remains, the same basis is obvious - the standard, its acceptance, fulfilment or violation.

For what can be the young people nowadays reproved? It concerns primarily the unclarified lifelong goals and prospects, lack of discipline, self-control and responsibility, easy succumb to the problematic or even negative influences and last but not least an unrestrained and one-way consumer approach to life (Fontana, 1997). The same behaviour was also possible to notice at the preceding generations, let us commemorate the "gilded youth" of the sixtieth up to eightieth of the last century. A chiselled feature of this part of young people is also a raised self-confidence that is not in accordance with the professional knowledge, one's own experiences, nor with the decent forms of social behaviour. These characteristics are often negatively reflected in the relation to:

- Duties (placed by standards, superior, older colleague with experiences and also the voluntary chosen ones);

- Other people (rudeness, thoughtlessness, selfishness, aggressiveness, cynicism);

- Values (intellectual, material);

- Oneself (resolution, life aspirations, daily regime, lifestyle).

The themes that the general public would hear of were perhaps overly stressed in the recent period and only with undue shyness was adopted a view that the democratic society, apart from the respect to the freedom of individuals, requires also a large extent of responsibility, internal discipline and to put not inconsiderable effort into achievement of the set goals and into overcoming of the demanding life situations. Particularly the symbolic motto" freedom" has been in many spheres understood absolutely and without restrain: neither in the sense of having a free hand in conflict with the violence, nor contrary to the faith in unquestioning obedience - but as an individual assertion without limits and restrictions. All sorts of evil and vice are then tolerated in the name of freedom, as conscience, emotion, taste, tact, feeling of responsibility, fellowship, standards and moral standards are understood as infringement of the personal "sovereignty". The freedom, conceived in this way requires the same starting line for everybody, in the interest of equal opportunity social justice, this line is however infringed by social, ethnic and political inequalities. The living reality but ever more shows that without respect to the authority and a meaningful regime - i.e. something common, unifying, and equally valuable for everybody, the society, family and school do not fulfil its role, loose its value, firmness, certainty and their basic functions. 


\section{Finally - the need of living satisfaction}

The way in which our old age will be going through depends also on our personal approach to it and on an active lifestyle. Sometimes it is possible to notice some older people and seniors who radiate happiness and look many years younger than their peer group. These people have certain common qualities. For example they are interested in other people, in their fate, they are empathetic, tolerant, optimistic, they keep social contacts, have a lot of interests and activities. Any kind of contact with other people belongs to the mental conditioning. It represents a precondition for not being isolated and lonely... People need people. The older we are, the more we need them, and no less. Some of the seniors still work and the feeling of usefulness provides them with happiness. In the real life we also can notice people, who are for example disabled, confined to a wheel chair but in spite of this fact they know how to enjoy trifles, they do not envy the motion to other people, on the contrary they are able to offer them help and encourage them should they have any problem. These people do not give up their life immediately after the first complications, they are able to take the bull by the horns and continue to tread down the right living path. On the contrary the people who wrap up in themselves with the first troubles, accuse other people of their own failures or envy them, cease to feel interest in their environment, fall into depressions and misery, and weaken thus their organism. All this subsequently leads to many health complications (Holeček, 2014).

Happy older people and seniors used to be sufficiently self-confident and do not give up at the first opportunity. They usually set themselves now goals that they would like to achieve (for example a foreign language course, computer course, course of drawing) and thanks to these goals they have something to live for. The self-confidence helps them to create firm, warm sincere, authentic and simple relations with other people and supports also intimacy. It facilitates a constant adaptability to everything that comes, loosens our energy, supports the creativity, enables us to overcome limits, use our talent, strength and our own potential. Let us therefore live our life to the fullest, enjoy every moment, and of course keep in mind that not a single moment will repeat. Every day can be the last one so it should be rewarding. Let us live in such a way that at the end of each day we can say - the present day turned out well."

\section{References}

ADORNO, Theodor W. a FRENKEL-BRUNSWIK, Else. The Authoritarian personality. New York: Harper \& Row, 1950. 989 s. Studies in Prejudice / edit. by Max Horkheimer and Samuel H. Flowerman.

ADORNO, Theodor W. et al. The authoritarian personality. 1. publ. New York: Norton, 1969. xxxiii, 990 s. Studies in prejudice. The Norton library; N492. ISBN 0-393-00492-9.

ARENDT, Hannah. Between past and future: eight exercises in political thought. New York: Penguin Books, 1993. 306 s. ISBN 0-14-018650-6. 
FONTANA, David. Psychologie ve školní praxi (Psychology in the school practice). Překlad Karel Balcar. Praha: Portál, 1997. 384 s. ISBN 80-7178-063-4.

FUCHS, Alfréd. Autorita (Authority). Praha: Melantrich, 1930. 133 s. Výhledy. Knihy zkušeností a úvah; sv. 3.

HOLEČEK, Václav. Psychologie v učitelské praxi (Psychology in the teaching practice). Vyd. 1. Praha: Grada, 2014. 223 s. Pedagogika. ISBN 978-80-247-3704-1.

KUČEROVÁ, Stanislava. Problém vztahu autority, hodnot a ideálů pohledem současné mládeže (The relationship between authority, values and ideals of today's youth look). In: VALIŠOVÁ, Alena a kol. Autorita ve výchově: vzestup, pád, nebo pomalý návrat (Authority in education: the rise, fall, or slow return). Praha: Karolinum, 1999. 185 s. ISBN 80-7184-857-3.

NOVOTNÝ, Petr. Autoritářství jako jedna z determinant výkonu učitelské profese. (Authoritativeness as one of the determinants of performance of the teaching profession). Pedagogika Praha: 47, 1997, No. 3, p. 247-257. ISSN 0031-3815.

RICH, John Martin. Discipline and authority in school and family. New York: Lexington Books, 1982. ISBN 978-0669051681.

VALIŠOVÁ, Alena a kol. Autorita v edukační a sociální práci (Authority in education and social work). Pardubice: Univerzita Pardubice, 2012. 411 S. ISBN 978-80-7395-507-6.

VALIŠOVÁ, Alena. Jak získat, udržet a neztrácet autoritu (How to attract, retain, and lose authority). Praha: Grada, 2008. 141 s. ISBN 978-80-247-2282-5.

VÝROST, Jozef a SLAMĚNÍK, Ivan. Sociální psychologie = Sociálna psychológia (Social psychology). Praha: ISV, 1997. 453 s. Psychologie. ISBN 80-85866-20-X.

WEBER, Max. Autorita, etika a společnost: pohled sociologa do dějin (Authority, Ethics and Society: A look into the history of the sociologist). Překlad Jan J. Škoda. Praha: Mladá fronta, 1997. Souvislosti; sv. 11. ISBN 80-204-0611-5.

WRÓBEL, Alina. Wychowanie a manipulacja. Kraków: Impuls, 2006. 188 s. ISBN 978-83-7308-600-5. 